\title{
Adoption of Cell-Phone Banking among Low-Income Communities in Rural Areas of South Africa
}

\author{
Nhlanhla Mlitwa, Nondumiso Tshetsha \\ IT Department, Faculty of Informatics and Design, Cape Peninsula University of Technology (CPUT), Cape Town, South Africa. \\ Email: Mlitwan@cput.ac.za,200712489@cput.ac.za
}

Received May $2^{\text {nd }}, 2012$; revised May $30^{\text {th }}, 2012$; accepted June $17^{\text {th }}, 2012$

\begin{abstract}
The maturity of interactive ICT solutions, with related convergence of various services on mobile platforms has revolutionised the way we communicate, and conclude business transactions in the informationage. The rise of e-Commerce, e-Business, e-Health, e-Learning or even internet and mobile phone banking, have simplified and improved access to these basic services for those who can exploit them. To enjoy these benefits however, one needs more than access, but also awareness and willingness to use these tools. The problem in most rural areas is that the majority still lacks awareness and literacy to make effective use of converged technologies in improving their lives. This study was set to explore the understanding of cell-phone banking by rural communities in South Africa. A qualitative approach was followed where individuals from informal settlements of Gugulethu and Nyanga were interviewed to determine whether they acknowledge the existence of cell-phone banking and to understand their reasons for non-usage. A vast majority of the low-income individuals according to the findings, do not use cell-phone banking. In fact, some do not even know what it is, and among the few that know about it most were not using. There are several issues that could possibly make rural individuals not to use or even trust cell-phone banking. Key among these was lack of insight into the facility, most probably, due to a lack of awareness. Issues of trust, where a mobile device is hardly construed as a viable alternative tool to handle one's finances, also emerged strongly in the findings. Therefore, maybe banking institutions need to initiate a marketing strategy that would best suit the rural individuals. Maybe South African government should intervene because they strongly emphasise on the need for rural development.
\end{abstract}

Keywords: ICT; Cell-Phone Banking; Internet Banking; Network Connectivity; Mobile Solutions; Remote \& Rural Areas

\section{Introduction}

The new information and communication technologies (ICT) have redefined the way modern societies conduct their academic, business and social lives. With the convergence of services delivered over networked technology, tools such as computers and mobile phones, learning, working and entertainment has not only become easier, but also reachable to the most remote communities.

One of the convenient but also the most accessible technology tool is the mobile phone. Additional capabilities have further seen an increase in its versatility. With the Internet now accessible over mobile phones for example, it is easier for people without the traditional Internet connection to access inter-networked services. It has also become possible for rural and remote communities to use their phones to conduct various services online. For example, they may use their mobile phones for internet or cell-phone banking, and to pay for rates and services without having to travel long distances to towns to perform these tasks.

Whilst mobile communication technologies offer numerous life-improving opportunities for the majority in underprivileged areas, unless the services are known and understood, people are not likely to exploit their benefits. The problem in South Africa however, is that despite the advantages presented by cell-phone banking, there is still a vast majority of people in rural areas who are not utilising it. According to the study conducted by Ivatury and Pickens [1], 300 out of 515 low-income bank clients (in the study) do not use cell-phone banking. Given the advantages of cost and process efficiency of cell-phone banking non-usage means continued costs on long distance travelling to and from the banks. It also means continued expenditure on heavy bank charges for transactions they could otherwise avoid through cell-phone banking. Whilst cell-phone banking promises to simplify the way banking is conducted, the lack of access to this facility by remote and rural people means they cannot make full use of banking services and its related benefits. 
This therefore is not in line with government policies in many developing countries such as South Africa that strongly emphasise the need for rural development, and social equity.

The study sought explanations on the limitations or lack of cell-phone banking usage by people in remote areas who stand to benefit the most from the facility. The objective was to understand the causes, understand the needs, and ultimately to find solutions to challenges of non-usage by people in remote areas. Hence, clarity was sought on the extent to which cell-phone banking is known, understood and used by people in remote and lower income areas. A question: "how is cell-phone banking understood and used by people in remote areas in South Africa” was a basis of the investigation.

The three concepts that were central to a research question of this study are cell-phone banking; the understanding of cell-phone banking, and remote areas:

- Cell-phone banking is defined as carrying out banking transactions and other related services via a cellphone, either through menu-driven or SMS technology [2];

- Understanding of cell-phone banking refers to the knowledge of the existence of cell-phone banking, its advantages and how to go about conducting it;

- Remote area is an isolated area where normally poor people live [3]. These areas are normally the last to get any development e.g. public services. Reference to the term "remote individuals" refers to the people who live in remote areas.

Otherwise, the rest of the paper is structured into a literature review, an outline of a research methodology, the findings, and the conclusion.

\section{Literature Review}

When wisely applied, networked technologies can improve the way people (either as individuals or groups) communicate, learn, work and enjoy convenient access to basic services [4,5]. According to Haddon [5], Internet has a potential to connect people across different cultures, regardless of location [4]. With Internet connectivity, individuals can use list-server-supported email tools to send messages to other users anywhere and at anytime [6]. The sending and receiving of emails is cost-effective and an easy means of exchanging and sharing information locally and internationally [4]. According to Haddon [5], email has replaced letter writing and has displaced faxes, which makes private and business communication much faster, efficient and convenient. Social networks as an emerging tool are adding an interactive convenience to internet-enabled communication [5]. The most popular social network is Facebook. In social networking people create their own space or homepage, where they write blogs, post pictures, videos and music; and share ideas with those who share similar interests [7]. For instance, a group of students can share their learning experiences, ideas and new opportunities.

\subsection{Inter-Connectivity \& Service Convergence}

Mobile technology such as cell-phones has equally improved the way individuals communicate and manage their private affairs. When cell-phones were introduced one of the few advantages they had was portability. As calls can be made on movable gadgets other than on fixed telephony lines, we are no longer constrained to stay at the home base to wait for messages [8]. Other added advantage of cell-phones is the ability to send text messages at a fraction of a phone call cost, and that one text message could be sent to several recipients at the same time [7]. Cell-phones are becoming more advanced every day. They have many features beyond sending messages and making calls. According to Gartner Inc. as found in Turban, et al. [7] by year 2009, close to 90 percent of mobile devices would have had features for sending and receiving email. This prediction was already confirmed in 2008, and by 2009 3G cell-phones could do even more-that is, in addition to the basic functions one can also send email, listen to radio, play music, play videos and transfer data files through the Bluetooth function.

The use of ICT's such as Internet, intranets and mobile computing are also changing the way organizations communicate and do business [7]. Organizations use the Internet to connect computers and other electronic devices via telecommunication networks. This enables individuals within organizations to access information stored in various places and be able to communicate (ibid.). Intranet is a network designed to serve internal informational needs of the organization, using Internet concepts [7]. Organizations use the Internet to provide information to the public about their products and services (ibid.). The use of the mobile phone has made communication easier for business people who travel regularly as it enables them to manage their affairs remotely while travelling, and this indicates mobility aspect of ICT [5]. As for employees, they are now able to access their company network from home through a desktop computer and wireline connection or be on the move with a laptop or PDA via wireless connection [7]. As most businesses are becoming Internet dependent (some being solely internet based), like Kalahari.net; referred to as e-Tailer [9]. With such businesses, it becomes a challenge for people with all these technologies (internet, cell-phones) if not fully equipped to utilize them.

Almost all banks offer electronic banking, comprising of Internet banking and mobile banking (cell-phone 
banking). Mobile banking as defined by Turban, et al. [7] is carrying out banking transactions and other related activities via mobile phone. Mobile banking is a more convenient way of banking, as people have unlimited access to their financial services and can make transactions anytime, anywhere. However, even with all these services available to people, it is quite a challenge when people are not knowledgeable to use their computers and mobile gadgets to access and benefit from these services. Through mobile banking, ICT improves the convenience of doing banking as people do not have to queue at the banks to make certain transactions. For an individual or even a business person, it means that they do not have to be at their offices or internet cafes to access internet and do banking but can actually do banking on their cellphones or PDA's. The aim of this study is to investigate the extent to which the benefits of this innovation are understood and exploited by all sectors of the community, especially those in remote areas distant from banking institutions.

\subsubsection{Cell-Phone Banking}

Cellphone banking is a convenient banking channel to manage your finances and is carried out through a cellphone handset. It enables individuals; for example, to check their bank balances, transfer funds between accounts, make payments to beneficiaries, enquire bank

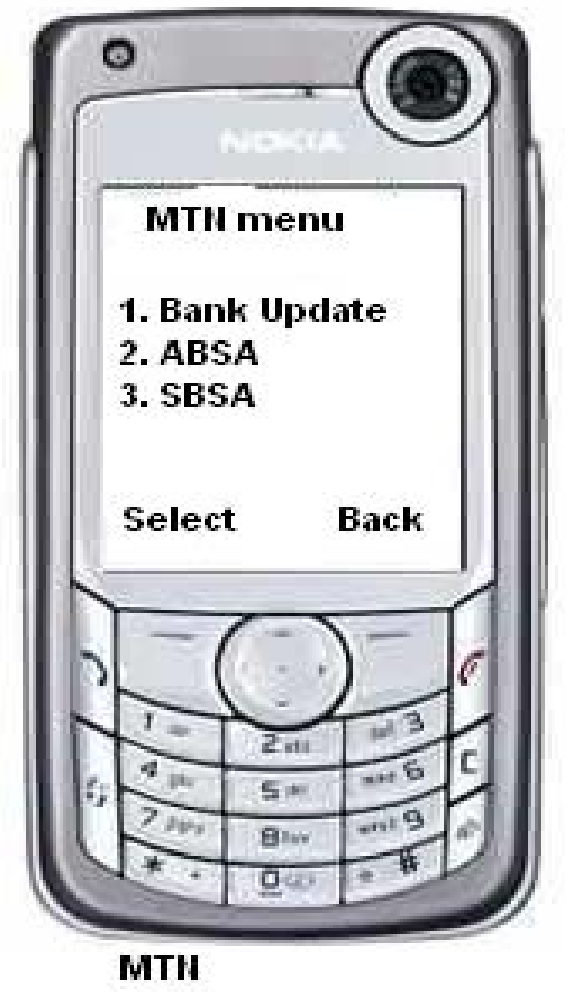

statements and buy airtime, anywhere, anytime [10-13]. With cellphone banking people are now no longer restricted to normal banking hours or geographical boundaries [10-13].

According to First National Bank (FNB) [12] and Nedbank [13], any valid Subscriber Identity Module (SIM) card can be used for cell-phone banking. To Register for cellphone banking you need to have a valid Identity Document (ID) number, bank account, a valid card number (the number written outside your bank card), as well as the auto-teller machine (ATM) pin number [1013]. Individuals can register for cell-phone banking at their nearest bank branch, via their cell-phones or by calling a 24-hour service line dedicated for cell-phone banking [10-13]. Once you get registered, the banking menu is downloaded into your cell-phone; for MTN users it is called MTN Menu, Vodacom it is called Vodata [10].

The authors of this study draw insight from the Amalgamated Banks of South Africa (ABSA), FNB, Standard Bank of South Africa (SBSA), and Nedbank online banking sources to describe three optional methods of conducting cellphone banking transactions. The paint program was used to construct graphical representations of these methods in Figures 1-5, which are the MenuBased; SMS and WAP methods.

The cellphone banking facility is encrypted by the same

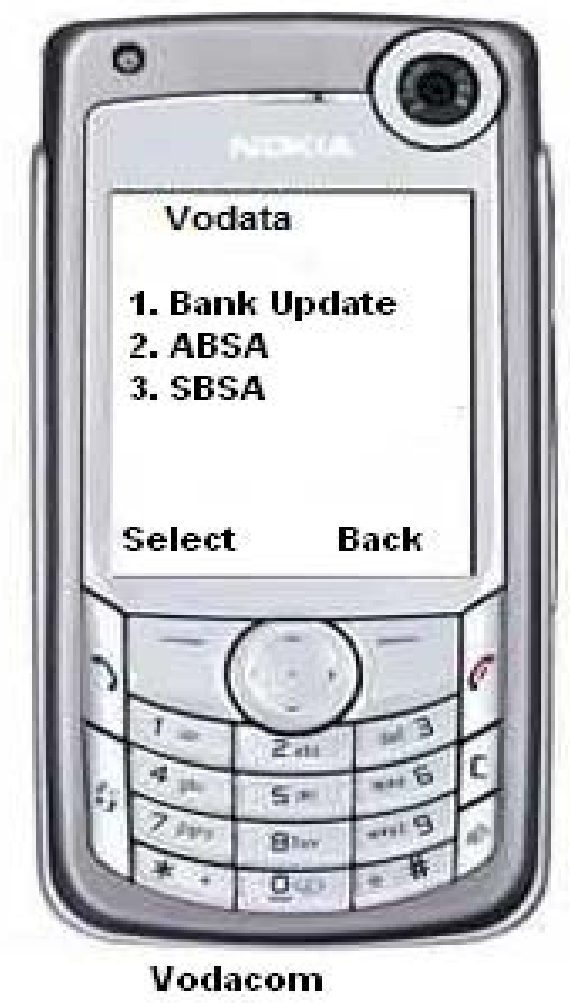

Figure 1. It shows ABSA menu-based cell-phone banking between MTN and Vodacom. 

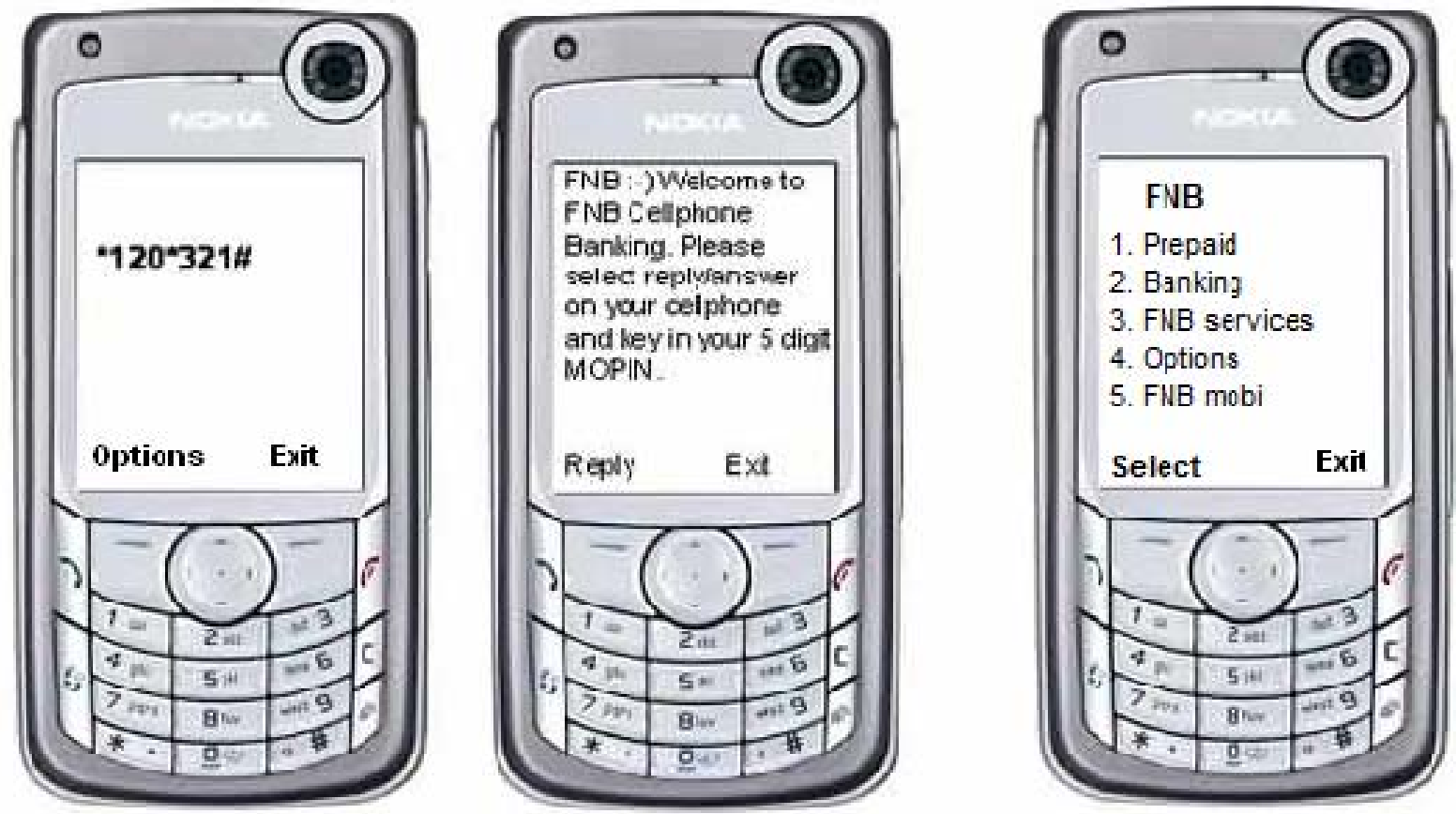

Figure 2. It shows FNB SMS-based cell-phone banking option; where you dial $* 120 * 321 \#$ then green button on your cellphone. Then a responsive SMS is sent to the user's cell-phone requesting the MOPIN (is a 5-digit cell-phone banking pin which you will be required to select at registration) [12]. The user will then receive different transactional options they can perform. The FNB SMS-based cell-phone banking is similar to other banks'; only differing in the SMS number users send their request to.
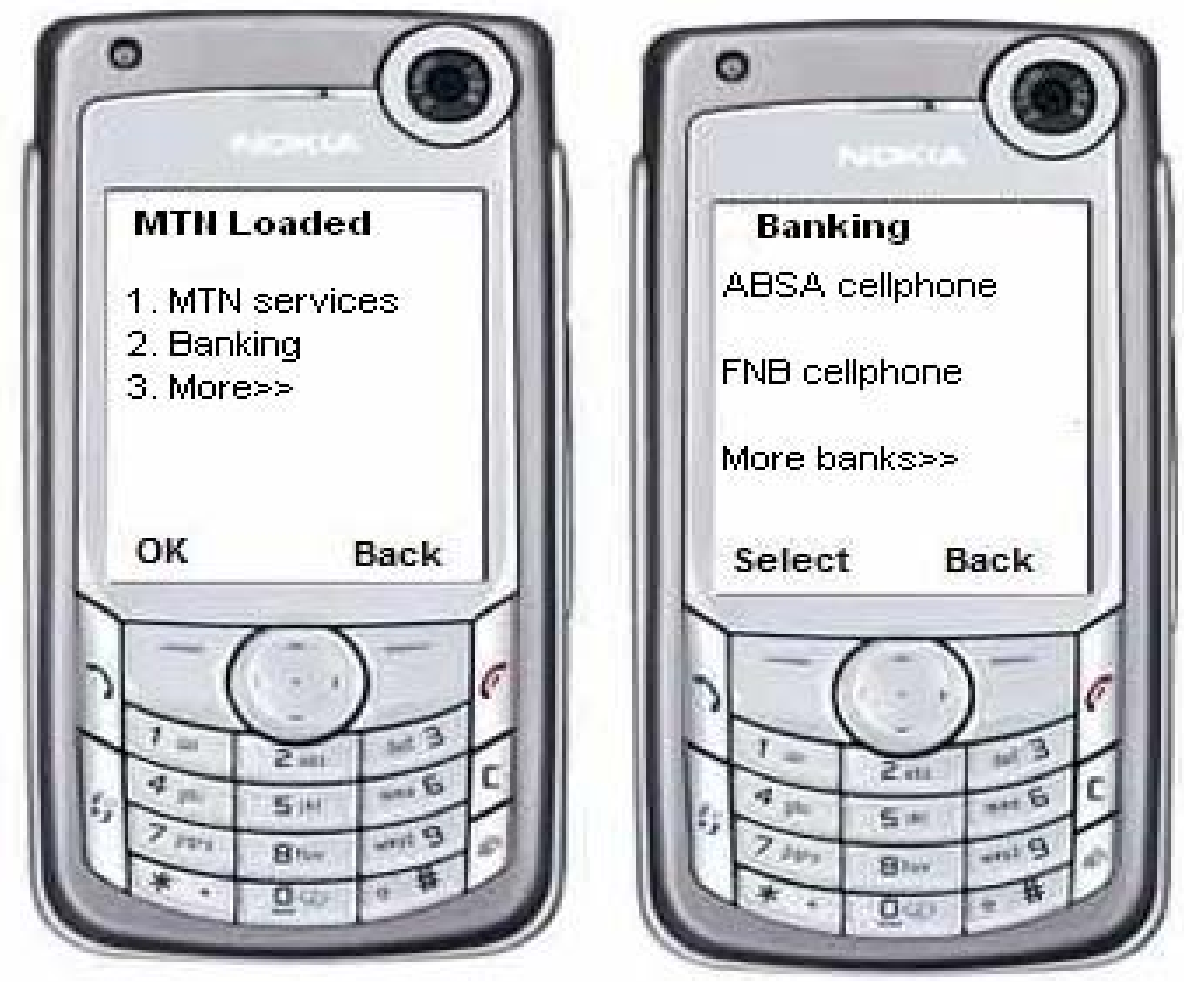

Figure 3. It shows how to access the cell-phone banking via WAP and Figure 4 below shows the log on screen, which is similar to that of menu-based cell-phone banking. It also requires account number, user number and Personal Identity Number (PIN). 

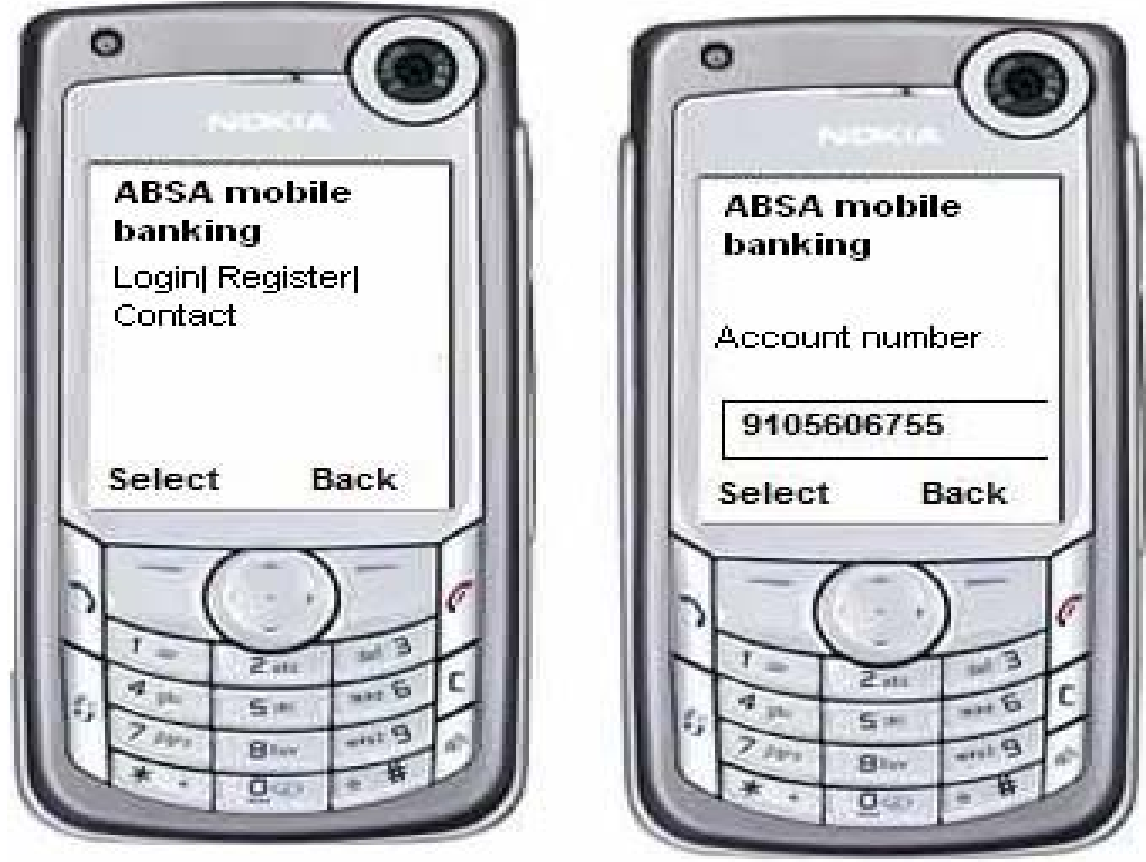

Figure 4. Log on steps to WAP.
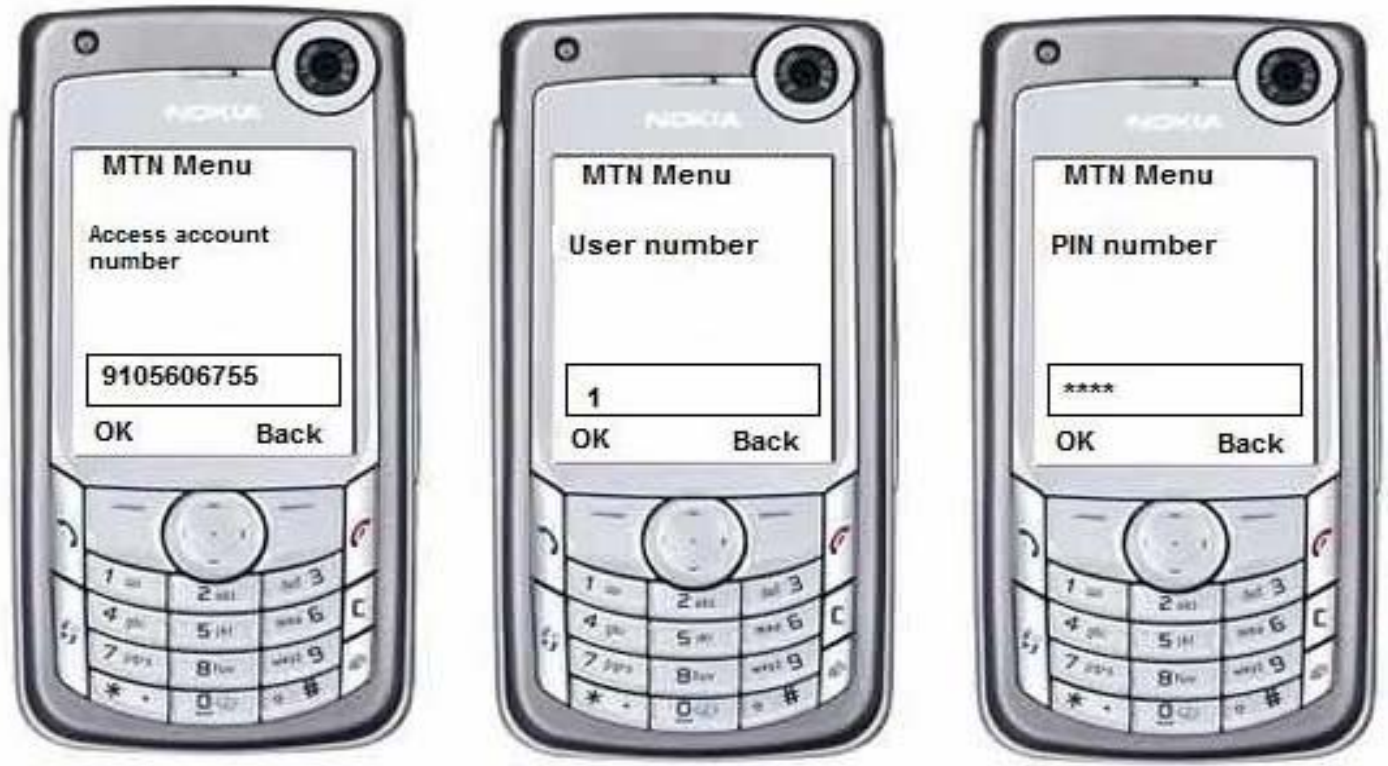

Figure 5. This shows log in process for ABSA Menu-based cell-phone banking service which is the same with the other banks; hence only one example is represented.

124-bit encryption used for internet banking. As part of security measures, individuals get notification via a text message, on any activity on their account [10-13]. Every time you log on, you need to provide an account number, user number and PIN number created at Registration. Individuals are encouraged to keep their PIN number safe at all times by not sharing it with anyone to ensure safekeeping of their accounts and to change their PIN num- bers regularly [10-13].

\subsubsection{Uses of Cell-Phone Banking}

This study clarifies the advantages of using cell-phone banking. It simplifies the process of doing banking by offering most banking transactions through cell-phone banking. It also reduces bank charges because cell-phone banking is free of charge, though your cell-phone needs 
to have credits (airtime) for you to start transacting. It also saves money in terms of travelling costs as you conduct banking in the comfort of your office or home. It offers convenience of mobility as you can conduct cellphone banking anywhere where there is cellular phone connectivity. Cell-phone banking is also well-known for its accessibility (anytime, anywhere) feature however there are connectivity issues attached to it more especially "in areas with unreliable wireless connectivity" [14]. The anytime, anywhere feature of cell-phone banking depends on the availability of the network provided by Mobile phone service providers such as MTN, Vodacom, Cell C, Orange, or Vodafone, among others, which is readily available in most rural areas.

However, these amazing benefits are infeasible to those who are not aware of them, or to those who are not literate enough to appreciate and exploit them.

Even for the literate, Mas and Kumar [14] argue that when customers use the cell-phone banking service for the first time, it is quite confusing but the more they use it, the more they get familiar with it and start appreciating it. It should be even be harder when one is not made aware of the facility. A distinction can be made between the traditional and the new ICT-based methods of doing banking, with the new methods adding flexibility and mobility. With Internet banking for example, one can access banking services in the comfort of their home or office, even beyond the traditional banking hours. The problem with Internet however, is that it remains a distant luxury for most people in remote and rural areas in the developing world [15]. Whilst the vast majority of people in remote areas would struggle to use internet banking due to a lack of access to computers and internet, almost everyone have a cell-phone, hence cell-phone banking is more accessible than other forms of networked banking.

Drawing on the GSM Association [16] report, Ivatury and Pickens indicate "the mobile phone" as having become "the first communications technology to have more users in developing countries than in developed ones". Statistics showing more than 800 million mobile phones having been sold in developing countries between 2003 and 2006, GSM Association [16] supports this claim. Thus "mobile phone usage expands", argues Ivatury and Pickens [16], "so many opportunities to bank the unbanked".

Cell-phone banking has extended mobility advantages. It extends the mobility in that one is no longer constrained to networked offices or home, and can do banking from any locations where there is cellular network connectivity. In addition, cell-phone banking could save people in rural and remote areas time and money in terms of travelling fares and bank charges, as almost all cellphone banking transactions are free of charge. Time is also saved, as people will not have to visit their banks as often as they used to.

\section{Research Methodology}

The proposed study will follow a qualitative method approach in order to understand remote people's understanding, knowledge and acceptance of cellphone banking. According to Maree, et al. [17], a qualitative method seeks to explore and understand a "central phenomenon" which is the concept or process explored in this study is cellphone banking”.

Table 1 represents the sampling process, which outlines the units of analysis, units of observation, data sources, data collection tools, and the outline of the number of participants.

Four units of analysis, cellphone banking descriptive information, background content, bank marketing strategies, and knowledge of cellphone banking are outline in Table 1. Data to describe cellphone banking was sourced from literature, more specifically, the websites of the four bank institutions: ABSA; FNB; Nedbank; Standard Bank which are the units of observation in this study.

Background and methodology data is also sourced from literature, including books, journals and the Internet. Similarly, data on bank strategies to market cellphone banking was sourced from banking four selected banking

Table 1. The Sampling Process.

\begin{tabular}{|c|c|c|c|c|}
\hline Questions & Data Source & Tools & Units of Observation & $\begin{array}{l}\text { Number of } \\
\text { participants }\end{array}$ \\
\hline $\begin{array}{l}\text { Cell-phone banking descriptive } \\
\text { information }\end{array}$ & Literature & Reading; analysing & $\begin{array}{c}\text { Websites of: ABSA; FNB; Nedbank; } \\
\text { Standard Bank }\end{array}$ & 4 institutions \\
\hline $\begin{array}{l}\text { Background \& Methodology } \\
\text { content }\end{array}$ & Literature & Reading; analysing & Academic Books, Journals; Internet & \\
\hline $\begin{array}{l}\text { Bank strategies to market } \\
\text { cell-phone banking }\end{array}$ & $\begin{array}{l}\text { Banking } \\
\text { institutions }\end{array}$ & Reading, analysing & $\begin{array}{c}\text { Websites of: ABSA; FNB; Nedbank; } \\
\text { Standard Bank }\end{array}$ & 4 institutions \\
\hline $\begin{array}{l}\text { Knowledge \& usage patterns } \\
\text { of cell-phone banking }\end{array}$ & $\begin{array}{l}\text { Individuals from } \\
\text { remote areas }\end{array}$ & $\begin{array}{l}\text { Interviews; } \\
\text { questionnaires; } \\
\text { analysing }\end{array}$ & $\begin{array}{l}\text { Men and women with income; in the age } \\
\text { of } 25 \text { - 50; residing in Gugulethu \& } \\
\text { Nyanga informal settlements. }\end{array}$ & $\begin{array}{l}10 \text { men } \\
10 \text { women }\end{array}$ \\
\hline
\end{tabular}


banking was sourced from banking four selected banking institution's websites. Lastly, data on knowledge and usage patterns of cell-phone banking was sourced from 20 individuals (10 men and 10 women) between the working ages of 25 and 50 are temporarily residing in informal settlements of Gugulethu and Nyanga in the Western Cape. Reading and analysing the content of the literature, as well as conducting interviews with bank officials and with individuals, were the data collection tools used in this study.

\section{Findings}

The interview was conducted on ten women and ten men residing in informal settlements of Gugulethu and Nyanga in the Western Cape to represent the rural people; see Appendix A for interview questions asked to the participants and Appendix B for their responses. The research objective was to learn how people in low income and remote areas in South Africa understand and use cellphone banking. To address this question, respondents were asked to describe their understanding of cellphone banking (see Appendice A and B).

In terms of the findings, twenty participants (ten women and ten men) were interviewed. On the understanding of cell-phone banking, only one out of twenty participants understood and was using cell-phone banking to its full potential. This participant stated that she uses cell-phone banking for transferring money to her kids at home in the Eastern Cape, buys airtime and checks balances on her account (Female \#1). According to this lady, the most outstanding advantage of cell-phone banking is the fact that it can be carried out anytime, anywhere without having to queue at the bank. Whilst one out of twenty participants is a statistically small percentage, the advantages of cell-phone banking described by this single participant confirms arguments in the literature that the facility improves convenience, saves time and improves efficiency in conducting banking transactions [14].

Nevertheless, the rest of the participants had limited to non-existent understanding of the concept of cellphone banking. For example, five male and seven female participants said that they are using cell-phone banking for receiving notifications, which is a very limited interpretation of cell-phone banking. In effect, cell-phone (mobile banking) as defined by Turban, et al. [7] is more than just receiving notifications of transactions, but encompasses carrying out banking transactions and other related activities via mobile phones. There is a difference between understanding the concept, but choosing to use only a fraction of the package, and reducing the meaning of the concept into just one aspect of the phenomenon. Assuming that receiving notifications is all that is meant by cellphone banking therefore, suggests a very minimum understanding of the phenomenon of cell-phone banking among people in remote areas. The rest of the participants did not know anything about cell-phone banking. This means that these people will not incur the benefits of cell-phone banking, such as saving on travelling costs to and from the bank, saving on banking charges (as indicated in Section 3.1.1). The status-quo brings into the questions the efficacy of the awareness initiatives and marketing programmes of the local banks, at least in getting the message through to the rural and low income customers.

There seem to be misperception among some participants that cell-phone banking is for a specific type people in a certain economic and income bracket. One of the reasons for not bothering understanding and use cellphone according to Female \#6, is that it "is probably for the rich people". It is an unfortunate misperception because cell-phone banking is designed for everyone from rural to urban areas. Others are purely sceptical. For example, after the facility was explained, one participant (Male \#6) cited a number of security threats relating to a high rate of banking scams reported, to dismiss the value of cellphone banking. A lack of awareness, and therefore non-usage of this facility among low-income people from remote areas in South Africa is therefore, apparent. To this effect, Mass and Kumar [14] state that cell-phone banking is always confusing for clients at initial stages, and the apparent clueless-ness suggests a need for increased vigilance in awareness and educational campaigns on the subject. As indicated in Section 4.3 of this paper, cell-phone banking is designed with security measures like passwords; encryption and notifications on account transactions and customers would benefit from the facility if they could be sensitised to this effect.

\section{Analysis}

The findings in this research shows that people in remote areas are still not benefiting from innovations of cellphone banking as envisioned by banking institutions. Responses to research questions on the understanding of the concept show a clear lack of awareness about the facility among this segment of the population. There could be other underlying causes or reasons like illiteracy and even lack of knowledge when it comes to their cellphone devices. A partial explanation to the status quo can be linked to a comment by Len Pienaar in 2008 [12], the CEO of FNB's Mobile and Transact Solution, saying that their "cellphone banking is not only offering innovative solutions but also targeting the mainstream market which is where their development strategy was focused". If FNB's cellphone banking strategy is targeted at the mainstream market, then the answer lies in what is meant by 
the "mainstream market". It is questionable whether the low income, remote and rural population is included in this category, as the majority of this sector is still "in the dark about" the basic meaning and the practical intricacies of cellphone banking. At this point we can conclude that remote individuals have a limited knowledge of cell-phone banking.

Cynics may argue: "why make such a fuss about the use or non-usage of cell-phone banking among the rural community?" From the digital divide perspective however, it is evident that rural communities experience complex social conditions where they need to travel long miles to towns only to check if there has been a deposit in their accounts. To this effect, cell-phone banking may not be a luxury but a cost saving and an absolute necessity for rural people. To answer "how is cell-phone banking understood and used by remote individuals in South Africa?” rural people are still not benefiting from cellphone banking innovation. A challenge therefore arises for both the financial institutions and local development entities, to embark on educational and awareness campaigns on the meaning, the benefits and the practical intricacies of cellphone banking among the rural people.

\section{Conclusion}

Considering that the majority of those who stand to benefit most from cell-phone banking are still not using it, maybe banking institutions need to use another marketing strategy that would best suit the rural market. They further need to ensure that security measures are in place to address concern of security threats raised during the interviews. Individuals need to do their bit as well, for instance ensuring that they know their cell-phone functionalities as lack of knowledge might expose them to further security risks.

\section{Limitations of the Study}

Since this project was for learning purposes there was no funding available to visit as many rural areas as one would have preferred, hence interviews were held with individuals residing in Gugulethu and Nyanga informal settlements. Though valid, spreading the sample to even wider audience would have added more comparative insight into the study.

\section{REFERENCES}

[1] G. Ivatury and M. Pickens, "Mobile Phone Banking and
Low-Income Customers: Evidence from South Africa, CGAP, United Nations Foundation, Vodafone Group Foundation,” 2006. http://www.cgap.org/publications/mobilephonebanking.pdf

[2] R. Tiwari, "Mobile Commerce: Mobile Banking, a Strategic Analysis of Opportunities in the banking Sector," University of Hamberg Research Project, 2006. http://www.uni-hamburg.de/m-commerce/banking/index_ e-html

[3] N. Mlitwa, "Higher Education and ICT in the Information Society: A Case of UWC, in CIRN2005," 2nd Annual Conference on Community Informatics Research Network (CIRN), Cape Town, 24-26 August 2005.

[4] L. Green, “Communication, Technology and Society,” Sage Publications, New York, 2001,

[5] L. Haddon, "Information and Communication Technologies in Everyday Life: A Concise Introduction and Research Guide,” Berg, London, 2005.

[6] J. Preece, "Online Communities Designing Usability, Supporting Sociability,” John Wiley \& Sons, Ltd., Hoboken, 2001.

[7] E. Turban, D. Leidner, E. McLean and J. Wetherbe, "Information Technology for Management Transforming Organizations in the Digital Economy,” 6th Edition, John Wiley \& Sons, Inc, Hoboken, 2008.

[8] E. Mante-Meijer, L. Haddon, P. Concejero, L. Klamer, J. Heres, R. Ling, F. Thomas, Z. Smoreda and I. Vrieling, "Checking It out with the People-ICT Markets and Users in Europe,” Report for EURESCOM, Heidelberg, 2012. http://www.eurescom.de/public/projects/P900-series/p903 /default.asp

[9] S. Pather, D. Remenyi and de la Harpe, "Evaluating ECommerce Success: A Case Study,” The Electronic Journal of Information Systems Evaluation, Vol. 9, No. 1, 2006, pp. 15-26. http://www.ejise.com

[10] ABSA Online, 2009. http://www.absa.co.za

[11] Standard Bank (SBSA) Online, 2009. http://www.standardbank.co.za

[12] FNB Online, 2009. http://www.fnb.co.za

[13] Nedbank Online, 2009. http://www.nedbank.co.za

[14] I. Mas and K. Kumar, "Banking on Mobiles: Why, How, for Whom?” CGAP, Washington DC, 2008.

[15] Bridges.org, "Telecommunication Liberalization-What Does It Mean for the Average Citizen?” 2001.

[16] GSM Association, "GSM Hits Two Billion Milestone," GSM Association, London, 16 June 2006.

[17] K. Maree, J. W. Creswell, L. Ebersohn, L. Eloff, R. Ferreira, N. V. Ivankova, J. D. Jansen, J. Nieuwenhuis, J. Pietersen, V. L. P. Clarck and van der C. Westhuizen, "First Steps in Research,” Van Schaik, Pretoria, 2007. 


\section{Appendix}

Summary of key points in interviews.

\begin{tabular}{|c|c|}
\hline MALE & FEMALE \\
\hline $\begin{array}{l}\text { Female \#1: } \\
\text { 1. Yes (she knows cell-phone banking). } \\
\text { 1.1. It is when you do banking through your cell-phone like buying } \\
\text { airtime, checking your balance or transferring money. } \\
\text { 2. She heard about it from a family member } \\
\text { 3. Yes, for balance on her bank account and buying airtime. } \\
\text { 4. Nothing it was all easy. } \\
\text { 5. The fact that you can use it anytime and anywhere without standing on } \\
\text { queues. }\end{array}$ & $\begin{array}{l}\text { Male \#1: } \\
\text { No, he doesn't know anything about cell-phone banking. }\end{array}$ \\
\hline $\begin{array}{l}\text { Female \#2: } \\
\text { 1. Yes, } \\
\text { 2. She uses it for notifications only }\end{array}$ & $\begin{array}{l}\text { Male \#2: } \\
\text { Only uses it for notifications. }\end{array}$ \\
\hline $\begin{array}{l}\text { Female \#3: } \\
\text { 1. yes } \\
\text { 2. She uses it for notifications only. }\end{array}$ & $\begin{array}{l}\text { Male \#3: } \\
\text { Only uses it for notifications. }\end{array}$ \\
\hline $\begin{array}{l}\text { Female \#4: } \\
\text { 1. She knows about cell-phone banking but not using it. } \\
\text { 2. A bank teller informed her about it. }\end{array}$ & $\begin{array}{l}\text { Male \#4: } \\
\text { Never heard of cell-phone banking. }\end{array}$ \\
\hline $\begin{array}{l}\text { Female \#5: } \\
\text { Only uses it for notifications }\end{array}$ & $\begin{array}{l}\text { Male \#5: } \\
\text { Only uses it for notifications. }\end{array}$ \\
\hline $\begin{array}{l}\text { Female \#6: } \\
\text { 1. No, she never heard of it. } \\
\text { 2. She also said it’s probably for "rich" people. }\end{array}$ & $\begin{array}{l}\text { Male \#6: } \\
\text { I have heard about it but would not use it for security risks } \\
\text { attached to it, relating to the banking scams happening. }\end{array}$ \\
\hline $\begin{array}{l}\text { Female \#7: } \\
\text { Notifications }\end{array}$ & $\begin{array}{l}\text { Male \#7: } \\
\text { No, I don't use cell-phone banking but was told about it at the } \\
\text { bank. }\end{array}$ \\
\hline $\begin{array}{l}\text { Female \#8: } \\
\text { Notifications }\end{array}$ & $\begin{array}{l}\text { Male \#8: } \\
\text { Only uses it for notifications. }\end{array}$ \\
\hline $\begin{array}{l}\text { Female \#9: } \\
\text { Notifications }\end{array}$ & $\begin{array}{l}\text { Male \#9: } \\
\text { Only uses it for notifications. }\end{array}$ \\
\hline $\begin{array}{l}\text { Female \#10: } \\
\text { Notifications }\end{array}$ & $\begin{array}{l}\text { Male \#10: } \\
\text { No, I don't use cell-phone banking but was told about it at the } \\
\text { bank }\end{array}$ \\
\hline
\end{tabular}

